\title{
LET Results of BSEd and BEEd of the Bulacan Agricultural State College (BASC): An Analysis
}

\author{
Edna Mae D. Cruz, Maria Krisvie Abigale F. Mendoza, Herbert M. De Jesus
}

\begin{abstract}
The quality of teacher education program can be gauged in the performance of graduates in the licensure examinations given by the Professional Regulation Commission (PRC). In this study, the performance of the Teacher Education graduates of Bulacan Agricultural State College (BASC) in the Licensure Examination for Teachers (LET) from 2013 to 2016, was evaluated. Results show that first time takers of the BSEd and BEEd programs perform higher than the average national passing rates with an average difference of $30.85 \%$ and $34.72 \%$, respectively. However, the repeaters in both programs performed lower at $\mathbf{- 1 9 . 7 2 \%}$ and $\mathbf{- 6 . 6 1 \%}$. For the first timers, BSEd takers performed slightly higher as revealed by their average passing rate of $64.97 \%$ as compared to $64.85 \%$ of the BEEd takers. For the repeaters, the BSEd average passing rate of $14.39 \%$ is lower than $23.52 \%$ of that of the BEEd. Similarly, for the overall performances, BSEd's rating of $32.89 \%$ is somewhat lower than that of the BEEd's rating of $42.15 \%$. The trend is, for the same year of administration of the examinations, the result for August/September examinations were higher than that of January/March for both the two programs. The result of this research supports the importance of review in passing the LET.
\end{abstract}

Index Terms-BSEd, BEEd, Education graduates, Licensure Examination for Teachers, Analysis

\section{INTRODUCTION}

A globally competitive teacher education program in the Philippines means raising it to the professional level. This was realized by the passing of Republic Act 7836, otherwise known as Philippine Teachers Professionalization Act of 1994 [1] which assigned the Professional Regulation Commission (PRC) to strengthen the supervision of and regulation of the teaching profession. As specified in Article IV, Section 27, the Commission prescribed the Licensure Examination for Teachers (LET). Thus, the quality of teacher education program can be gauged in the performance of graduates in this licensure examination. This periodic assessment is considered as an actual indication of the value of training the teacher education institutions (TEIs) have inculcated to their students.

In the recent study conducted by the Philippine Business for Education (PBEd), LET takers registered only a depressing $31 \%$ passing rate. The study showed that 497 out of 1,024

Edna Mae D. Cruz, Institute of Education, Arts and Sciences, Bulacan Agricultural State College, Pinaod, San Ildefonso, 3010 Bulacan Philippines

Maria Krisvie Abigale F. Mendoza, Institute of Education, Arts and Sciences, Bulacan Agricultural State College, Pinaod, San Ildefonso, 3010 Bulacan Philippines

Herbert M. De Jesus, Institute of Education, Arts and Sciences, Bulacan Agricultural State College, Pinaod, San Ildefonso, 3010 Bulacan Philippines
TEIs who had graduates take the elementary examination under LET performed below the national passing rate. The same goes for 637 out of 1,258 TEIs for the secondary examination. This is a strong indication that teacher education institutions are of low quality because less than half actually are above or are performing above national average and more than half are performing below national average [2]. This also reveals that there is a necessity to scrutinize the performance of the teacher education institutions for most are not producing quality graduates who will teach the youth of the country [3].

Even though many schools have developed and implemented contingency plans, including BASC - Institute of Education, Arts and Sciences (IEAS), they still fall short of accomplishing the expected results. For these reasons, the researchers come together and devise this study.

\section{OBJeCtives}

This study evaluated the performance of the Teacher Education graduates of Bulacan Agricultural State College (BASC) in the Licensure Examination for Teachers (LET) from 2013 to 2016.

Specifically, it analyzed the:

1.1 performance of the Bachelor of Secondary Education and Bachelor of Elementary Education LET takers as compared to the national passing rate of both first timers and repeaters;

1.2 performance of the BSEd as compared to the BEEd takers for both first timers and repeaters; and

1.3 trends in the performance for both group of takers.

\section{MATERIALS AND METHODS}

This study made use of the licensure examination results from the certification issued to the College by the PRC from March 2013 to September 2016. The difference between the institutional and national passing rates of January/March and August/September results were utilized in the analysis.

\section{RESULTS AND DISCUSSIONS}

The following presents the analysis of the LET results of the BSEd and BEEd graduates of BASC. 
Table 1.1a. Secondary Education LET Results (First Timers)

\begin{tabular}{|c|c|c|c|c|c|}
\hline \multirow{2}{*}{$\begin{array}{l}\text { Examination } \\
\text { Periods }\end{array}$} & \multicolumn{3}{|c|}{ Institutional (BASC) } & \multirow{2}{*}{$\begin{array}{c}\text { National } \\
\text { Passing Rate (\%) }\end{array}$} & \multirow{2}{*}{ Differenc } \\
\hline & Takers & Passers & Passing Rate $(\%)$ & & \\
\hline Sep-16 & 65 & 37 & 56.92 & 33.78 & 23.14 \\
\hline Mar-16 & 11 & 7 & 63.64 & 35.43 & 28.21 \\
\hline Sep-15 & 53 & 36 & 67.92 & 41.75 & 26.17 \\
\hline Mar-15 & 16 & 10 & 62.50 & 31.64 & 30.86 \\
\hline Aug-14 & 44 & 28 & 63.64 & 34.41 & 29.23 \\
\hline Jan-14 & 8 & 5 & 62.50 & 28.41 & 34.09 \\
\hline Sep-13 & 34 & 23 & 67.65 & 39.75 & 27.90 \\
\hline Mar-13 & 12 & 9 & 75.00 & 27.78 & 47.22 \\
\hline Average & & & 64.97 & 34.12 & 30.85 \\
\hline
\end{tabular}

Table 1.1a shows the result for BSEd LET takers (first timers). The passing percentage of the first timers in eight examination periods are above the national passing percentage with an average difference of $30.85 \%$ and $34.72 \%$. The highest institutional passing rate was recorded in March 2013 (75.00\%). The lowest institutional passing rate was in September 2016 (56.92\%), albeit this result still exceeds the national passing percentage at $27.78 \%$ and $33.78 \%$, respectively. This indicates that despite the longer exam for the BSEd, first time takers performed well.

Table 1.1b. Secondary Education LET Results (Repeaters)

\begin{tabular}{|c|c|c|c|c|c|}
\hline \multirow{2}{*}{$\begin{array}{l}\text { Examination } \\
\text { Periods }\end{array}$} & \multicolumn{3}{|c|}{ Institutional (BASC) } & \multirow{2}{*}{$\begin{array}{c}\text { National } \\
\text { Passing Rate (\%) }\end{array}$} & \multirow{2}{*}{ Difference } \\
\hline & Takers & Passers & Passing Rate $(\%)$ & & \\
\hline Sep-16 & 42 & 2 & 4.76 & 33.78 & -29.02 \\
\hline Mar-16 & 53 & 18 & 33.96 & 35.43 & -1.47 \\
\hline Sep-15 & 92 & 44 & 47.83 & 41.75 & 6.08 \\
\hline Mar-15 & 67 & 13 & 19.40 & 31.64 & -12.24 \\
\hline Aug-14 & 105 & 30 & 28.57 & 34.41 & -5.84 \\
\hline Jan-14 & 49 & 9 & 18.37 & 28.41 & -10.04 \\
\hline Sep-13 & 85 & 26 & 30.59 & 39.75 & -9.16 \\
\hline Mar-13 & 48 & 23 & 47.92 & 27.78 & 20.14 \\
\hline Average & & & 28.92 & 34.12 & -5.19 \\
\hline
\end{tabular}

In Table 1.1b, LET results of repeaters show that all, except in March 2013 and September 2015, the institutional passing rates for the eight examination periods were below the national passing rate with an average difference of $-5.19 \%$. This very unsatisfactory performance is due to the fact that the takers graduated several years before taking the exam for the second time around or may be third time and had no refresher course or had not attended any review class before taking the exam again.

Table 1.1c. Secondary Education Overall Performance

\begin{tabular}{|c|c|c|c|c|c|}
\hline \multirow{2}{*}{$\begin{array}{c}\text { Examination } \\
\text { Periods }\end{array}$} & \multicolumn{3}{|c|}{ Institutional (BASC) } & \multirow{2}{*}{$\begin{array}{c}\text { National } \\
\text { Passing Rate }(\%)\end{array}$} & \multirow{2}{*}{ Difference } \\
\hline & Takers & Passers & Passing Rate $(\%)$ & & \\
\hline Sep-16 & 107 & 39 & 36.45 & 33.78 & 2.67 \\
\hline Mar-16 & 42 & 11 & 26.19 & 35.43 & -9.24 \\
\hline Sep-15 & 39 & 8 & 20.51 & 41.75 & -21.24 \\
\hline Mar-15 & 51 & 3 & 5.88 & 31.64 & -25.76 \\
\hline Aug-14 & 61 & 2 & 3.28 & 34.41 & -31.13 \\
\hline Jan-14 & 41 & 4 & 9.76 & 28.41 & -18.65 \\
\hline Sep-13 & 51 & 3 & 5.88 & 39.75 & -33.87 \\
\hline Mar-13 & 36 & 14 & 38.89 & 27.78 & 11.11 \\
\hline Average & & & 18.36 & 34.12 & -15.76 \\
\hline
\end{tabular}

Table 1.1c presents the overall performance of the BSEd LET takers in the last four years. It was noticed that all, except in March 2013 and September 2016, the institutional passing rates were below the national passing rates having an average difference of $-15.76 \%$. Additionally, the high performance average difference for the first timers (30.85\%) in Table 1.1a was pulled by the low performance average difference of the repeaters $(-5.19 \%)$ in Table $1.1 \mathrm{~b}$. It indicates that the repeaters performance greatly affected the overall results.

Table 1.2a. Elementary Education LET Results (First Timers)

\begin{tabular}{cccccc}
\hline $\begin{array}{c}\text { Examination } \\
\text { Periods }\end{array}$ & Takers & $\begin{array}{c}\text { Institutional (BASC) } \\
\text { Passers }\end{array}$ & $\begin{array}{c}\text { Passing Rate (\%) } \\
\text { Passing Rate (\%) }\end{array}$ & Difference \\
\hline Sep-16 & 70 & 40 & 57.14 & 30.18 & 26.96 \\
Mar-16 & 12 & 8 & 66.67 & 28.39 & 38.28 \\
Sep-15 & 64 & 31 & 48.44 & 31.36 & 17.08 \\
Mar-15 & 18 & 10 & 55.56 & 27.42 & 28.14 \\
Aug-14 & 67 & 43 & 64.18 & 35.74 & 28.44 \\
Jan-14 & 11 & 10 & 90.91 & 28.98 & 61.93 \\
Sep-13 & 59 & 31 & 52.54 & 31.18 & 21.36 \\
Mar-13 & 6 & 5 & 83.33 & 27.78 & 55.55 \\
\hline Average & & & 64.85 & 30.13 & 34.72 \\
\hline
\end{tabular}

For the BEEd, Table 1.2a shows the results of the first timers. It can be gleaned on the table that unlike the BSEd, they garnered higher percentage of passing than the national passing rate in all examination periods. Results revealed that they performed best in January 2014 exam with only one among the eleven takers failed. This indicates that first timers performed well in the LET for the past four years.

Table 1.2b. Elementary Education LET Results (Repeaters)

\begin{tabular}{cccccc}
\hline $\begin{array}{c}\text { Examination } \\
\text { Periods }\end{array}$ & Takers & $\begin{array}{c}\text { Institutional (BASC) } \\
\text { Passers }\end{array}$ & $\begin{array}{c}\text { Passing Rate (\%) } \\
\text { Passing Rate (\%) }\end{array}$ & Difference \\
\hline Sep-16 & 34 & 3 & 8.82 & 30.18 & -21.36 \\
Mar-16 & 42 & 5 & 11.90 & 28.39 & -16.49 \\
Sep-15 & 30 & 3 & 10.00 & 31.36 & -21.36 \\
Mar-15 & 42 & 19 & 45.24 & 27.42 & 17.82 \\
Aug-14 & 39 & 4 & 10.26 & 35.74 & -25.48 \\
Jan-14 & 41 & 20 & 48.78 & 28.98 & 19.80 \\
Sep-13 & 40 & 4 & 10.00 & 31.18 & -21.18 \\
Mar-13 & 44 & 19 & 43.18 & 27.78 & 15.40 \\
\hline Average & & & 23.52 & 30.13 & -6.61 \\
\hline
\end{tabular}

Table $1.2 \mathrm{~b}$ shows the performance of the BEEd repeaters. Results reveal that the repeaters' performance is fairly because five out of eight examination periods, the institutional passing rate were all below the national passing rate having an average difference of $-6.61 \%$. It indicates that retaking the exam long after graduation without any refresher course or attending review class reduces their chance to pass the licensure exam. 
Table 1.2c. Elementary Education Overall Performance

\begin{tabular}{cccccc}
\hline $\begin{array}{c}\text { Examination } \\
\text { Periods }\end{array}$ & Takers & Passers & Passing Rate (\%) & $\begin{array}{c}\text { National } \\
\text { Passing Rate (\%) }\end{array}$ & Difference \\
\hline Sep-16 & 104 & 43 & 41.35 & 30.18 & 11.17 \\
Mar-16 & 54 & 14 & 25.93 & 28.39 & -2.46 \\
Sep-15 & 94 & 34 & 36.17 & 31.36 & 4.81 \\
Mar-15 & 60 & 29 & 48.33 & 27.42 & 20.91 \\
Aug-14 & 106 & 47 & 44.34 & 35.74 & 8.60 \\
Jan-14 & 52 & 30 & 57.69 & 28.98 & 28.71 \\
Sep-13 & 99 & 35 & 35.35 & 31.18 & 4.17 \\
Mar-13 & 50 & 24 & 48.00 & 27.78 & 20.22 \\
\hline Average & & & 42.15 & 30.13 & 12.02 \\
\hline
\end{tabular}

Presented in Table 1.2c is the overall performance of the BEEd LET Takers for the last four years. The institutional passing rates were all higher than the national passing rates having an average difference of $12.02 \%$, except for March 2016. This result shows that repeaters greatly influenced the overall LET performance of BASC.

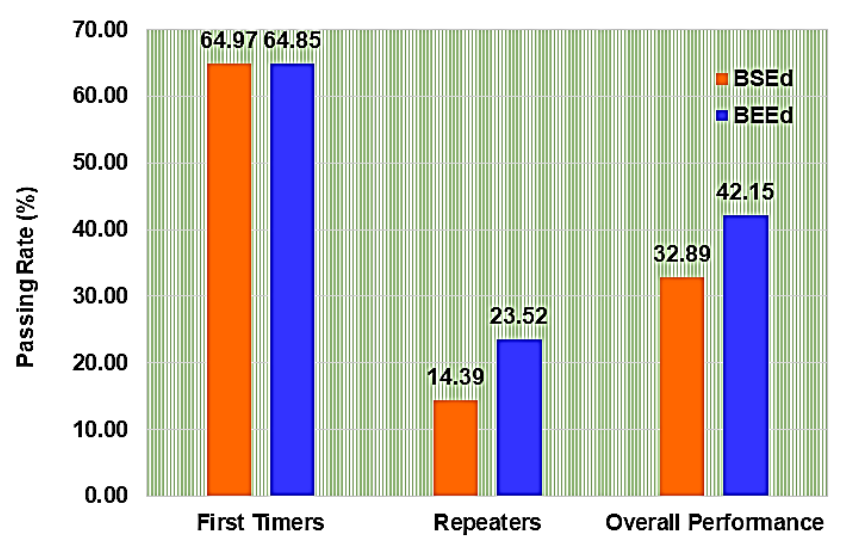

Graph 1. Comparison of the BSEd and BEEd Average LET Performances

Graph 1 shows the comparison between the BSEd and BEEd LET performances. For the first timers, BSEd takers performed higher as revealed by their average passing rate of $64.97 \%$ as compared to $64.85 \%$ of the BEEd takers. For the repeaters, the BSEd average passing rate of $14.39 \%$ is lower than $23.52 \%$ of that of the BEEd. Similarly, for the overall performances, BSEd's rating of $32.89 \%$ is somewhat lower than that $42.15 \%$ that of the BEEd.

As regards to the trend in the performance of the teacher education graduates who took the Licensure Examination for Teachers from $2013-2015$, results expose that the institutional passing rate for first timers were always higher than the national passing rates for the two programs, whereas, it is always a reverse for the repeaters. Another trend is, for the same year of administration of the examinations, the result for August/September examinations were higher than that of January/March for both the two programs. The latter result strengthens the role of review in passing the LET.

\section{CONCLUSIONS}

Based on the data presented, it is concluded that both the BSEd and BEEd first time LET takers had a higher passing rate; the first timers performed far better than the repeaters;
BSED takers perform slightly better than the BEEd in all the examination periods; and the rate of passing in both programs for August/September examinations were higher than that of January/March results.

\section{RECOMMENDATIONS}

With the conclusions made, it is hereby recommended that attendance to a review class or study sessions be a requirement for LET takers; repeaters may be required to take refresher courses with certification to be presented to the PRC, before they can be allowed to apply for another examination; and Teacher Education institutions like that of College of Education may come up with interventions to help their graduates who failed in the LET and succeed in retaking the exam.

\section{REFERENCES}

[1] Republic Act 7836 (1994). Philippine Teachers Professionalization Act of 1994 (enacted).

[2] Cepeda, M. (2017, October 2). Half of PH schools for teachers perform poorly in licensure exams. Retrieved November 10, 2017, from

https://www.rapller.com/nation/184062-worst-best-schoolsteachers-licensure-examination

[3] Laganao, E. (2017). In Focus: College of Education Graduates Licensure Examination for Teachers (LET) Performance. Journal of Social Sciences \& Humanities Research,1-4. Retrieved October 10, 2017, from http://jsshr.anveshika.org/article/in-focus-college-of-education -graduates-licensure-examination-for-teachers-let-performance I

Edna Mae D. Cruz Ph. D. in Education, major in Physics Education student at the University of the Philippines Open University. Presently Associate Professor I at the Bulacan Agricultural State College handling physics, mathematics and other basic sciences courses.

Maria Krisvie Abigale F. Mendoza Ph. D. in Education, major in Science student at the Nueva Ecija University of Science and Technology. Presently Instructor I at the Bulacan Agricultural State College handling chemistry and professional education courses.

Herbert M. de Jesus Master of Arts in Education, major in Science graduate and Assistant Professor I at the Bulacan Agricultural State College. He is presently the Chair of the Bachelor of Secondary Education program, also from the same school. 